\title{
New insights into epididymal function in relation to sperm maturation
}

\author{
Jean-Louis Dacheux and Françoise Dacheux \\ UMR INRA-CNRS 7247, 37380 Nouzilly, France \\ Correspondence should be addressed to J-L Dacheux; Email: Jean-louis.dacheux@orange.fr
}

\begin{abstract}
Testicular spermatozoa acquire fertility only after 1 or 2 weeks of transit through the epididymis. At the end of this several meters long epididymal tubule, the male gamete is able to move, capacitate, migrate through the female tract, bind to the egg membrane and fuse to the oocyte to result in a viable embryo. All these sperm properties are acquired after sequential modifications occurring either at the level of the spermatozoon or in the epididymal surroundings. Over the last few decades, significant increases in the understanding of the composition of the male gamete and its surroundings have resulted from the use of new techniques such as genome sequencing, proteomics combined with high-sensitivity mass spectrometry, and gene-knockout approaches. This review reports and discusses the most relevant new results obtained in different species regarding the various cellular processes occurring at the sperm level, in particular, those related to the development of motility and egg binding during epididymal transit.

Reproduction (2014) 147 R27-R42
\end{abstract}

\section{Introduction}

The formation of fertile spermatozoa is the result of spectacular stages of cell differentiation that begin in the male gonad and finish in the female tract. The initialization and formation of the male gamete take place in the epithelium of the seminiferous tubules and are characterized by a series of genetically timecontrolled cellular modifications. The spermatozoon developed at the output of the testis is morphologically complete but immotile and unable to fertilize an oocyte. For all mammals, this fertilization ability of the spermatozoon is the result of discrete post-gonadal differentiation stages that occur during transit along the several meters of the epididymal tubule. These modifications occur in a male gamete that lost its transcriptional and translation abilities during the last stages of spermatid differentiation. It is postulated that such postgonadal sperm differentiation is controlled by the surrounding environment. Such extracellular control of gamete differentiation, also called 'epididymal sperm maturation', appears to be unique in the body. Several investigations have been undertaken over more than 60 years to understand the mechanisms involved in the development of fertility of the male gamete.

The post-gonadal stages of sperm differentiation are set up by successive modifications that occur when the gamete transits specific parts of the epididymal tubule. At the same time, outside the gametes, the composition of the luminal epididymal environment also changes sequentially throughout the epididymis. In view of these two parallel events, most investigations have involved assessing the relationships between these two events and identifying the epididymal signals able to control spermatozoon fertility.

The most recent research using new techniques such as transcriptomic and proteomic approaches has involved identification of these events occurring on/in the sperm and in their surrounding epididymal environment. The role of certain epididymal and sperm proteins involved in this sperm maturation has also been investigated by gene deletion in mice. Furthermore, as epididymal sperm maturation is a common phenomenon in mammals, comparative studies have been developed to identify mechanisms common between species that could be the fundamental mechanisms of post-testicular differentiation.

\section{The epididymal sperm environment: a specific continuously modified milieu}

From their haploid stage, the male germ cells are isolated from the rest of the body by a blood barrier that is present from the testis to the deferent duct. Such restrictive exchange results in the formation of a unique sperm environment controlled successively by Sertoli cells and by epididymal epithelium activity. The epididymal fluid is certainly the most sequentially modified milieu of the body in which the spermatozoa are bathed for 1 or 
2 weeks. The most important change in this luminal fluid is induced by water reabsorption. This water movement occurs principally in the efferent ducts where almost $80-90 \%$ of the testicular fluid is reabsorbed and continues at a lower level up to the first part of the epididymis. These water changes through aquaporin channels are driven by the transepithelial movement of $\mathrm{Na}^{+}, \mathrm{Cl}^{-}$and $\mathrm{HCO}_{3}^{-}$and also result in important modifications in the ionic composition of the lumen fluid throughout the epididymal tubule (Da Silva et al. 2006).

The first consequence of such water movement is a spectacular increase in the luminal sperm concentration, increasing from $10^{8}$ spermatozoa $/ \mathrm{ml}$ in the rete testis fluid to $10^{9}$ in the deferent duct, with a maximum in the first part of the epididymis. The second consequence is the modification of the protein concentration from 2 to $4 \mathrm{mg} / \mathrm{ml}$ in the rete testis fluid and the initial segment of the epididymis to a maximum of $50-60 \mathrm{mg} / \mathrm{ml}$ in the distal caput. It then returns to $20-30 \mathrm{mg} / \mathrm{ml}$ in the more distal regions of the organ (Fouchecourt et al. 2000, Belleannee et al. 2011b, Dacheux et al. 2012). For all the mammals studied, these changes occur in the anterior part of the epididymis and are always associated with the first sperm modifications such as the migration of the cytoplasmic droplet, the beginning of flagellum beating and binding to the zona pellucida (ZP). As most of these sperm modifications have never been successfully induced in vitro for testicular spermatozoa, their triggers may have an epididymal origin. Among the epididymal factors potentially involved, it is becoming clearer that the surrounding proteins may be directly or indirectly involved in the changes in sperm properties during their transit through this organ.

\section{Composition, identification and origin of the luminal epididymal proteins}

Defining the protein composition of the epididymal fluid has been the aim of several studies since the 1970s-1980s (Turner et al. 1979, Brooks 1981). The first research in this field was carried out mostly to find specific epididymal proteins directly involved in sperm maturation and available as immunological targets for male contraception.

In such research, protein identification was based only on isolated proteins. Our understanding of epididymal proteins has increased spectacularly with genome sequencing and new proteomic technology using large-scale analysis in the last 10 years. Today, several hundred proteins can be identified using mass spectrometer technology in a single study. However, due to the huge range of protein concentrations in the epididymal fluid, spanning around 12 orders of magnitude, only four to six orders can be measured in a whole sample using the current most sensitive mass spectrometer. The complete identification of all luminal epididymal proteins thus remains a technological challenge.

Several hundred epididymal proteins have already been identified from the epididymal fluid of different species. All these epididymal fluids are characterized by the presence of proteins in high concentrations, and no more than 20 proteins represent $80-90 \%$ of the total luminal proteins (Fig. 1). Several of these proteins are common to different species such as lactoferrin (LTF), lipocalin 5 (LCN5, E-RAPB), clusterin (CLU), glutathione peroxidase (GPX5), prostaglandin D2 synthase (PTGDS), transferrin (TF), Niemann-Pick disease, type C2 (NPC2), phosphoethanolamine-binding protein 4 (PEBP4), $\beta$ - $N$-acetyl-hexosaminidase (HEXB), glutathione S-transferase (GST), gelsolin (GSN), actin (1.4\%), and $\beta$-galactosidase (GLB1). For the human epididymis, $77 \%$ of the total luminal proteins are represented by albumin (ALB) $(43.8 \%), \operatorname{CLU}(7.6 \%), \operatorname{NPC} 2(6 \%), \operatorname{LTF}(5.9 \%)$, extracellular matrix protein (ECM1) $(3.2 \%), \alpha 1$-antitrypsin (SERPINA1 (A1AT)) (2.7\%), PTGDS (2.2\%, $1.7 \%)$, TF $(1.3 \%)$, and actin (ACT) (1.2\%) (Dacheux et al. 2006). Most of these epididymal proteins are highly polymorphic due to glycosylation and other posttranslational modifications.

There are wide variations in the concentrations of these major proteins between species. No phylogenic studies have been carried out between mammalian species, but the major proteins seem to be a proteomic signature for closed species, as observed for bovine and ovine species (Dacheux et al. 2012). However, there is considerable divergence between extreme mammalian classes such as eutherians and monotremes. For monotremes such as the platypus, the luminal protein composition in the epididymis is unique among mammals, with numerous species-specific proteins such as E-OR20 (a new lipocalin), SPARC, and PXN-FBPL (Dacheux et al. 2009).

Most of the luminal proteins are actively secreted by the epididymal epithelium, but their secretion is dependent on the region of the organ. Such sequential secretion along the epididymal tubule results in a continuous change in the epididymal fluid proteome (Fig. 1). Furthermore, the secretion pattern is species specific, but several proteins can be found in similar epididymal regions (e.g. PTGDS, GPX5, and RNASE10 in the proximal epididymal regions and LT, NCP2, GSN, and several glucosidases in the middle and distal parts of the organ). However, for several other proteins, such as LCN5, principally secreted in the epididymal caput in the mouse but in the corpus cauda in the bull, ram, and boar, the secretory epididymal region is different (Dacheux et al. 2012).

Of all the major epididymal secreted proteins, the most commonly secreted is CLU. This protein, originally found to be a Sertoli cell secretion (Fritz et al. 1983), represents around $30 \%$ of the total epididymal secretion for all the species studied to date. Furthermore, this 

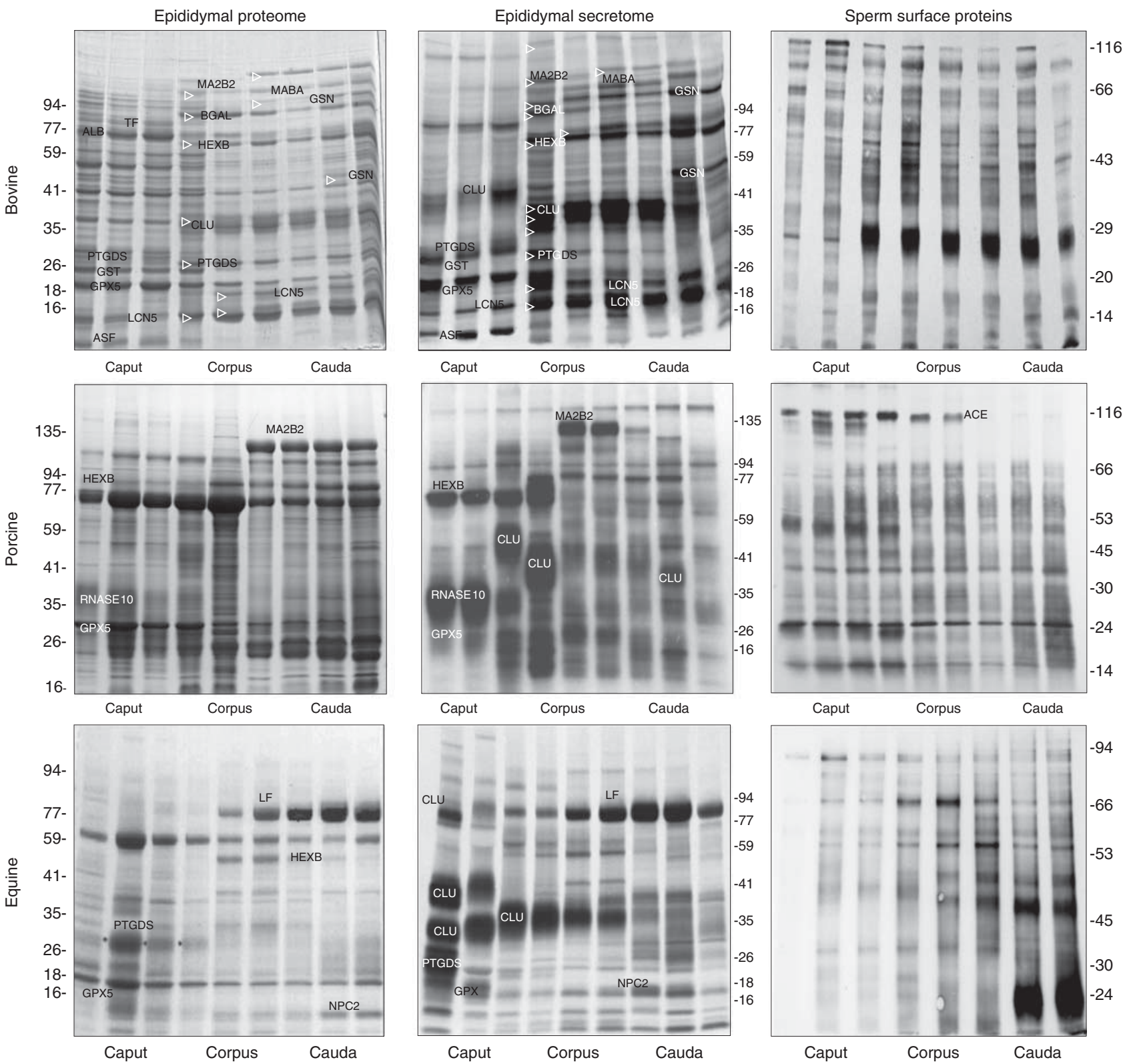

Figure 1 Epididymal proteome and secretome and sperm surface proteins of three species. For the proteome, the same quantity of epididymal proteins from nine zones of the epididymis corresponding to the three principal regions was separated by $1 \mathrm{D}$ gel electrophoresis and silver stained. The plates illustrating the secretory activities correspond to the autoradiograms of the same 1D gel separations presented for the proteome of the boar (Syntin et al. 1996), stallion (Fouchecourt et al. 2000), and bull (Belleannee et al. 2011b). The sperm surface proteins correspond to the 1D SDSPAGE, western blot, and streptavidin peroxidase detection of the NP40 extracts of the sulpho-NHS-biotin-labelled surface membrane proteins of spermatozoa collected from eight or nine epididymal zones (C Belleannnée and J L Dacheux, 2006 unpublished data).

protein can be secreted at different levels of the epididymis and as several isoforms (three in the horse and at least two in the bull and the ram).

The local concentration of a protein in the luminal fluid is generally related to the secretory activity of the adjacent epithelium. Thus, a major protein found in the luminal fluid corresponds to a major secretion. However, the concentration of each secreted protein is linked not only to its secretion but also to its reabsorption in specific epithelium regions. Some proteins or isoforms are present only in their secreted region (e.g. RNASE10, porcine, ovine and murine species (Castella et al. 2004), and some isoforms of CLU in equine species (Fouchecourt et al. 2000)). For other proteins such as GPX5, several glucosidases, and PTGDS (Fouchecourt et al. 2000, Belleannee et al. 2011b), the luminal concentration is modulated by their reabsorption intensity or by their accumulation during epididymal 
transit (e.g. lactoferrin in equine species and LCN5 in bovine species) (Dacheux et al. 2012).

Most of these major secretory proteins are soluble in the luminal fluid and secreted by conventional and unconventional secretion pathways for the proteins lacking signal peptides. However, several secreted proteins have been found to be highly hydrophobic such as the 17 and $22 \mathrm{kDa}$ ram epididymal proteins (extracted as lipoprotein) (Gatti et al. 2000), prion protein (PRP; Gatti et al. 2002, Ecroyd et al. 2005), and several glycosylphosphatidylinositol (GPI)-anchored proteins, such as CD52 (Kirchhoff 1996). The secretion mechanism of such hydrophobic proteins in the luminal fluid is still unclear. Some of these proteins have been found to be associated with luminal membrane vesicles. These vesicles are liberated from the surface of the principal cells as vesicular blebs (Ilio \& Hess 1994, Frenette et al. 2002, Hermo \& Jacks 2002, Gatti et al. 2005) and named 'epididymosomes' (see review by Sullivan \& Saez (2013)). However, secreted hydrophobic proteins are not only associated with such luminal membrane vesicles but also found in soluble high-mass protein complexes such as CLU, cauxin, PRNP, $17 \mathrm{kDa}$ hydrophobic protein, and several glycosidases (Ecroyd et al. 2005).

\section{Functions of the most abundant luminal epididymal proteins}

Most of the major epididymal proteins are also found in other tissues, and thus their general functions can be identified. However, their presence at high concentrations is surprising in the sperm environment. This is the case for the huge amounts of enzymes such as glycosidases ( $\alpha$-D-mannosidase, $\beta$-hexosaminidase, GLB1, $\alpha$-glucosidase, $\beta$-glucuronidase, etc.), numerous proteases (kallikrein, cathepsin A-D-H-L-S-L, gACE, ADAM2-7, furin, MMP2, etc.) and several protease inhibitors (serpin, eppin, CRES, serpin2, HE4, etc.). Most of these enzymes have been found to be active in vitro, except for certain specific epididymal proteins, such as RNASE10 (Castella et al. 2004). Several of these enzymes, such as different matrix metalloproteases (MMPs), are secreted as a pro-form and activated after processing in the fluid (Metayer et al. 2002).

However, the presence of such concentrations of active enzymes in vivo suggests the presence of enormous quantities of substrates, but to date such substrates remain hypothetical. It is also possible that the function(s) of these enzymes may be different from those displayed in other tissues. This can be illustrated by glutathione-independent PTGDS that is intensively secreted in the epididymal caput and known to catalyse the conversion of prostaglandin $\mathrm{H} 2\left(\mathrm{PGH}_{2}\right)$ to prostaglandin D2 $\left(\mathrm{PGD}_{2}\right)$, but in the epididymis its role is only as a carrier for hydrophobic substrates in the luminal fluid (Fouchecourt et al. 2002).
The other intriguing finding is the fact that some enzymes and their specific inhibitors (such as proteases and protease inhibitors) are found together in the same luminal fluid. This suggests that the enzymes' activities could be controlled and functional only in a limited part of the epididymis and blocked by specific inhibitors downstream during transit through the organ. Such sequential enzyme activity is highly probable, but it has not been demonstrated to date.

Thus, in addition to the sequential changes in the protein composition of the epididymal fluid, the activities of these proteins could also be sequentially controlled. Such duality between the presence and activity of an epididymal protein in a specific region makes their understanding in relation to spermatozoa more complex than expected.

Nevertheless, by analogy with the activity of these proteins in other tissues, several general functions of these proteins can be suggested in the epididymis. The most realistic function is protection of the sperm during epididymal transit. Several proteins successively secreted in the epididymal fluid may be involved in the reduction of reactive oxygen species in the luminal fluid such as GPX5 (Chabory et al. 2010, Taylor et al. 2013), thioredoxin, GSTM1-3, SOD1, and PRDX2-5. This protective function may also be illustrated by the presence of several proteins and peptides such as several $\beta$-defensins (Yamaguchi \& Ouchi 2012), lipocalins, and CRES proteins against bacterial attack (Wang et al. 2012).

The epididymal proteins may also be involved directly in the protection of active sites on the sperm surface, illustrated by the fact that when epididymal sperm are washed free from epididymal proteins, sperm headto-head agglutination occurs very rapidly. Such protection may be attributed to several proteins with binding properties such as CLU, lactoferrin, TF, apolipoprotein A-1, PEBP, and some other glycoproteins involved in the glycocalyx composition of the gamete (Fabrega et al. 2012).

Other important functions of epididymal proteins may be linked to molecular exchange or as carriers of hydrophobic components (e.g. cholesterol, retinoic acid, and androgen). Several epididymal proteins may be involved individually, such as NCP2, LCN5, PTGDS, androgen-binding protein (SHBG (ABP)), vitamin D-binding protein, lactoferrin, $\mathrm{TF}$, and ceruloplasmin (Guyonnet et al. 2011), or combined together in a soluble high-molecular mass lipophilic complex (Ecroyd et al. 2005).

Several potential roles may thus be attributed to these major luminal proteins, but they are still mostly hypothetical. In the mouse, the knockout $(\mathrm{KO})$ gene for several of these proteins (e.g. lactoferrin, SOD1, GSTM1, CLU, GPX5, PTGDS, LCN5, hexosaminidase, CRISP1, and CRISP4) does not result in a reduction in male fertility in vivo, except for the inactivation of the Rnase10 gene. 
The exact functionality and importance of all these major epididymal proteins, therefore, remain to be evaluated in relation to sperm survival, maturation in the epididymis and species diversity.

\section{Epididymal spermatozoa: continuous epididymal sperm surface modifications}

As for epididymal fluid composition, the spermatozoa are sequentially modified throughout their transit in this organ. One of most visible morphological changes is the migration of the cytoplasmic droplet, a remnant of the germ cell cytoplasm. This structure slides from the beginning to the end of the intermediate piece of the flagella in the middle part of the epididymal caput. The mechanism involved in this cytoplasmic migration has not been elucidated, but it is worth noting that the transport of this droplet occurs from a very restricted epididymal region that corresponds to the maximum concentration of spermatozoa in the lumen and where the epithelium protein secretions are the most active. The relationship between epithelium functions and molecular mechanisms of such cellular modification remain to be identified. Such migration is an important sign of sperm maturation, since any defect in droplet migration is related to a decrease in sperm fertility (Cooper 2005) but not to the activation of sperm motility in the epididymis.

The other relevant but less visible sperm modifications involve the membrane and sperm surface composition. Over several decades (Scott et al. 1967, Dacheux \& Voglmayr 1983), many studies have shown that numerous sequential changes occur in the lipid and protein composition of the sperm membrane during epididymal transit.

The characterization of these modifications was first oriented to those directly involved in egg-binding and -fertilization ability of spermatozoa. Based on the inhibition of sperm-oocyte binding/fusion with the use of specific antibodies, several surface proteins such as CRIP1 (protein D/E), acrosin, fertilin, PH20, IZUMO, and SPAM1 were identified (Supplementary Table 1, see section on supplementary data given at the end of this article). Several of these surface proteins are processed during epididymal transit by a cascade of proteolytic cleavages such as the well-documented ADAM family proteins (ADAM $1 / \alpha$-fertilin, ADAM2/ $\beta$-fertilin, and ADAM3/cyritestin). Most of these cleavages occur as soon as the gamete enters the epididymis or in the first part of this organ. The cleaved peptides of these proteins are either relocated in different plasma membrane domains (e.g. ADAMs) or released into the surroundings, as is the case for ACE, which becomes a major protein in the epididymal fluid for several species (Gatti et al. 1999).
Several sperm membrane proteins such as luminal epididymal proteins that bind to the surface of gametes (e.g. CRISP1, cathepsin, ADAM7, EPPIN, MAN2A2, SPAM1, MFGE8, GPX5, CLU, and MIF) have also been identified (Supplementary Table 1). Some of these proteins are adsorbed at the sperm surface by electrostatic interaction or are integrated into the plasma membrane. For hydrophobic and GPI-anchored proteins, the exchange between the epididymal secretion and the sperm membrane has not been completely resolved yet. It may be mediated by soluble intermediates such as the epididymal vesicles (epididymosomes) or soluble hydrophobic protein complexes present throughout the epididymal tubules. The quantity of epididymosomes appears to be relatively low and limited compared with the total number of spermatozoa (no more than $0.5 \%$ of the total volume of spermatozoa). Furthermore, the exact mechanism of protein transfer remains to be clarified, since the exchange is protein specific and not all proteins of the vesicles are transferred or retrieved on the sperm surface. Thus, if these vesicles are the potential major route of hydrophobic protein transfer, it may be via very subtle exchange mechanisms that remain to be elucidated.

Using these earlier identification approaches, sperm membrane modifications were studied protein by protein. However, other major protein modifications can be visualized on the sperm surface using more global surface labelling techniques such as surface protein biotinylation and 1D or 2D electrophoresis gel separation (Figs 1 and 2). Such approaches demonstrate that modifications occur continuously at the surface membrane level. It is assumed that most of the surface proteins originating from testicular gametes are modified or disappear and new compounds can be visualized in the terminal regions of the epididymis. Such modifications occur for all the mammalian species, but the protein characteristics and the patterns of the sequential changes involved are different between species (Fig. 1). Such species differences raise the question of whether rodents are the most appropriate model to study epididymal sperm maturation in other species.

The current challenge is the systematic identification of the sperm surface proteins involved in epididymal maturation, whatever the species, and particularly for human spermatozoa. Proteomic analysis is a promising approach to identify epididymal proteins. The first global proteomic studies on the male gamete were based on 2D gel electrophoresis separation. Such an approach has the advantage of separating and quantifying several thousand compounds and isoforms, but mainly the most abundant compounds and less well the high-molecular weight and hydrophobic proteins. Nevertheless, coupled with 2D LC-mass spectrometry, such proteomic approaches provide the opportunity to identify several proteins of the mature spermatozoon (see review by Brewis \& Gadella (2010)). 

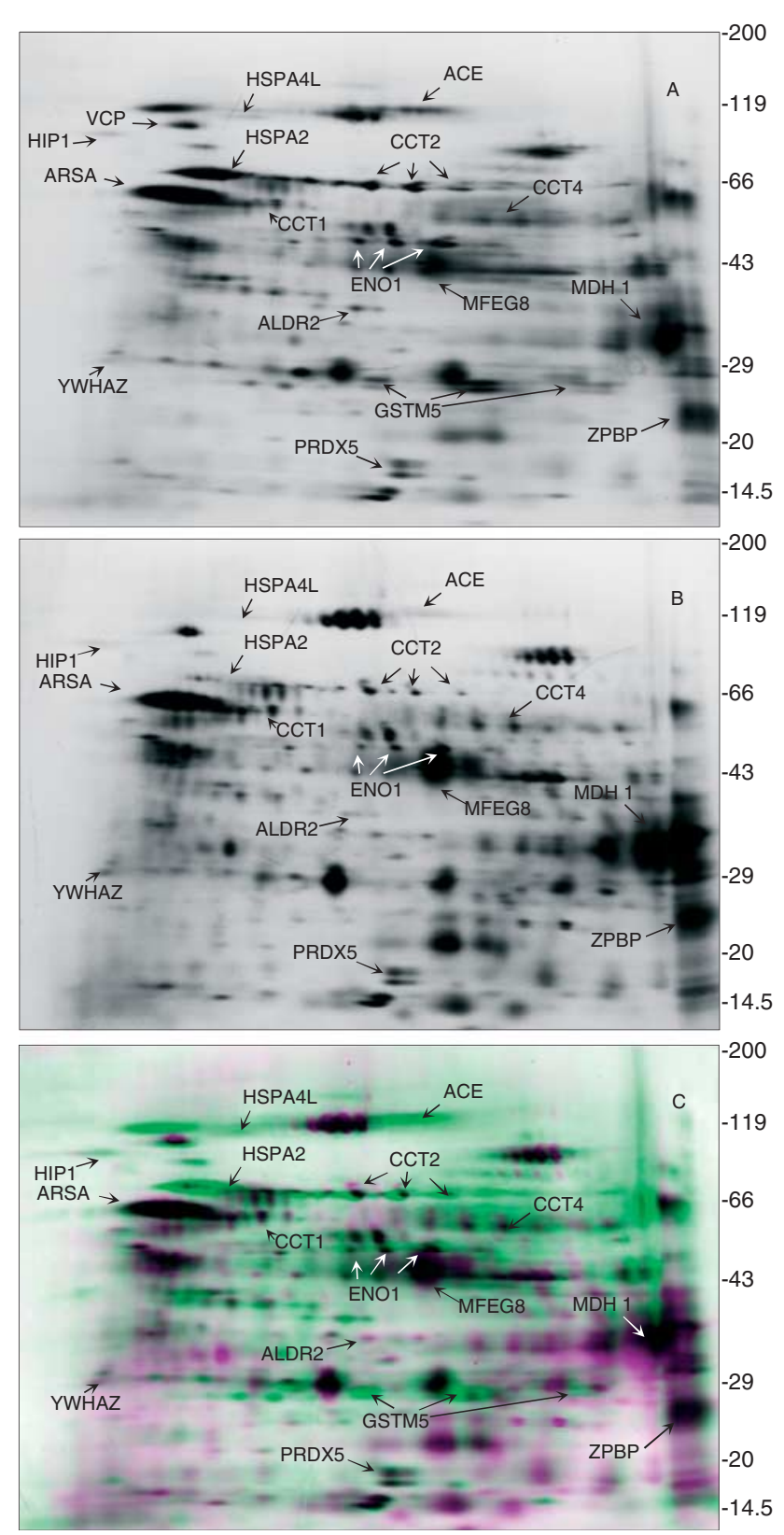

Figure 2 Silver staining of 2D separation of purified surface proteins from immature (A) and mature (B) epididymal boar sperm.

(C) Composite 2D gels from immature (green) and mature (red) sperm. Adapted from Belleannee C, Belghazi M, Labas V, Teixeira-Gomes AP, Gatti JL, Dacheux JL, Dacheux F 2011 a Purification and identification of sperm surface proteins and changes during epididymal maturation. Proteomics 11 1952-1964.

The recent improvements in mass spectrometer technology provide the opportunity to identify sperm proteins directly from the whole lysate of mature sperm without previous electrophoresis separation. In these 'deep proteomic analyses' (Oliva et al. 2009), several thousand proteins have been collected from mature spermatozoa (epididymal or ejaculated) of different species such as the mouse (Baker et al. 2008b, Chauvin et al. 2012), rat (Baker et al. 2008a), bull (Peddinti et al. 2008), and human (Johnston et al. 2005). The maximum number of proteins identified by this technique in human sperm is around 5000 (Wang et al. 2013).

Several methods of analysis have been developed to increase the identification of the low-abundance proteins on subcellular parts of the spermatozoa such as the head and flagellum (Cao et al. 2006, Amaral et al. 2013, Baker et al. 2013), acrosomal matrix, (Guyonnet et al. 2012), detergent-resistant membrane (Sleight et al. 2005, Nixon et al. 2009), phosphorylated proteins (Platt et al. 2009), and proteins involved in capacitation (Ficarro et al. 2003) and motility (Zhao et al. 2007, Martinez-Heredia et al. 2008, Chan et al. 2009) and of sperm-egg interactions (Stein et al. 2006, Petit et al. 2013). In spite of the lack of a dynamic range of mass spectrometers to identify the low-represented proteomes, these 'shotgun' mass spectrometer approaches provide the opportunity to identify additional proteins involved in new or unexpected metabolic pathways for mature sperm (Amaral et al. 2013).

Few systematic proteomic studies have been published about epididymal sperm maturation. Most of them have combined 2D gel electrophoresis and MS on the total extracts of immature and mature epididymal sperm from the mouse (ljiri et al. 2011), rat (Guo et al. 2007), or hamster (Kameshwari et al. 2010), or on subcellular compartments such as the head and flagella (Suryawanshi et al. 2011), acrosomal and membranous proteins (Park et al. 2012), and phosphopeptides (Baker et al. 2012), or on purified sperm surface proteins (Belleannee et al. 2011a). About 20 proteins involved in sperm maturation have been identified by these studies, of which only two or three have been found to be common between two studies or species. In view of the numerous changes visualized by specific labelling of the surface proteins during epididymal transit, many more proteins and their isoforms remain to be identified (Fig. 2).

\section{Relationship between epididymal activity and sperm maturation}

The principal characteristics of a 'mature' spermatozoon can be summarized as a male gamete that is able to activate its motility (forward and hyperactivated), be capacitated, bind to the pellucida, fuse to the oocyte membrane, and be able to result in a viable embryo. How can epididymal activity be involved in these essential sperm functions during transit of the gamete?

\section{Epididymal surroundings and sperm motility}

The most visible and quantifiable change in the epididymal sperm is the development of motility, the activation of which is the result of progressive steps. 
It begins with an increase in asymmetry and irregular flagella beating in the anterior part of the epididymis to reach symmetrical propagation of waves on each side of the flagella, inducing the forward motility of the spermatozoa in more distal parts of the organ (Bork et al. 1988, Chevrier \& Dacheux 1992). However, such motility is only observed in vitro when epididymal sperm have been washed free of epididymal fluids and diluted and incubated in an artificial medium. In vivo, weak beating flagella can be seen in the rete testis and efferent duct fluids, but after the increase in sperm concentration in the epididymal fluid, most of the spermatozoa maintain quiescent motility whatever the position in the epididymis.

Thus, for the majority of mammalian species, sperm motility in the epididymis is balanced by two important components: one concerning the final differentiation of the flagella machinery, which can be analysed only in vitro after its activation, and the other controlling or repressing this machinery to avoid sperm movement.

In vitro, sperm motility increases progressively from the corpus to the cauda epididymis, with testicular and caput epididymal sperm showing only irregular curvatures of the flagella. The progressive maturation of the complex interactions between tubulin and dynein molecules should occur during epididymal transit. However, it has been known for many years that forward motility can be induced in immature sperm in vitro. Such activation can be achieved with intact testicular spermatozoa (Dacheux et al. 1979, Okamura et al. 1991, Jaiswal \& Majumder 1996b), intact epididymal sperm (Acott et al. 1983, Smith et al. 1996, Vijayaraghavan et al. 1996), or demembranated immature sperm (White \& Voglmayr 1986, Ishijima \& Witman 1991, Patil et al. 2002). Such observations indicate that the flagellum machinery of the spermatozoon at the output of the testis is molecularly functional but inactivated in vivo.

Although these results have been known for several years, the exact mechanism of the activation of sperm motility in the epididymis is still unclear, particularly the influence of the epididymal surroundings. A few studies on the epididymal maturation of sperm motility have been published recently, with most of them being more focused on the potential capacitation of the epididymal sperm than on the motility process.

The motility of mature spermatozoa is dependent on the intracellular cAMP generated by adenylyl cyclase and on subsequent successive protein phosphorylations including protein kinase A (PKA), A-kinase anchor proteins (AKAPs) and many other phosphorylated proteins (see review by Turner (2006)). A cascade of very short (in the order of nanoseconds) phosphorylations and dephosphorylations of dynein arms is generated by serine/tyrosine kinases and serine/tyrosine phosphatases. Such activities induce active bend propagation and regular flagella beating by alternate sliding of microtubules along the length of the flagellum (Morisawa 1994).

During epididymal transit, the sperm's intracellular cAMP level increases from the corpus to the cauda (Hoskins et al. 1974, Dacheux \& Paquignon 1980, Pariset et al. 1985), simultaneously with metabolic capacity and ATP production (Inskeep \& Hammerstedt 1982). The production of cAMP is generated by an atypical sperm soluble adenylyl cyclase (sAC or SACY; Okamura et al. 1985, Wandernoth et al. 2010), which is biochemically distinct from the transmembrane adenylyl cyclases located throughout the sperm midpiece (Hess et al. 2005) and regulated by bicarbonate and calcium (Buck et al. 1999, Chen et al. 2000, Xie et al. 2006). The role of cAMP and adenylate cyclase in spermatozoa is now genetically established by $\mathrm{KO}$ of the Adcy10 (sAc) gene, which induces male sterility linked to a sperm motility defect (Esposito et al. 2004).

The control of the intracellular cAMP levels of the spermatozoa and consequently protein phosphorylation are the keys to understanding the gradual (potential) activation of motility during epididymal transit. The bicarbonate and $\mathrm{Ca}^{2+}$ concentrations are two important components of the luminal epididymal fluid that could directly control the intracellular cAMP concentrations in the epididymal spermatozoa and consequently activate protein phosphorylation and motility.

\section{Role of luminal bicarbonate in epididymal sperm motility}

The bicarbonate originating from the testis $(20 \mathrm{mM})$ in the lumen of the epididymal tubule is partially reabsorbed between the seminiferous tubules and the caput of the epididymis by the $\mathrm{HCO}_{3}^{-}$transporter (Breton 2001, Liu et al. 2012) and by carbonic anhydrase activity (Hermo et al. 2005). In the rat epididymis, the bicarbonate concentration is around 2-6 mM (Levine \& Marsh 1971), with a slight increase in the cauda and vas deferens being linked to bicarbonate secretion by the principal epididymal cells (see review by Shum et al. (2011)).

The intracellular concentration of bicarbonate in the epididymal spermatozoa is constitutionally regulated by $\mathrm{HCO}_{3}^{-}$transporters (SLC4 and SLC26 families), by $\mathrm{HCO}_{3}^{-}$-permeable transmembrane proteins (AE2 and CFTR) (Liu et al. 2012), and by carbonic anhydrase activity. All these regulatory enzymes are already present and potentially activated in testicular sperm except for carbonic anhydrase IV (CAR4). This enzyme appears on the sperm surface only when the gamete transits through the epididymal corpus (Ekstedt et al. 2004, Wandernoth et al. 2010) and is retained on the membranes of mature epididymal sperm (Stein et al. 2006) and ejaculated sperm (Ficarro et al. 2003).

During epididymal transit, the transport of $\left[\mathrm{HCO}_{3}^{-}\right]$ and $\mathrm{HCO}_{3}^{-}$in the spermatozoa decreases significantly. 
In the caput epididymis, the transport is over three times higher than that in the corpus and cauda epididymis (Okamura et al. 1988). For mature spermatozoa, the intracellular $\left[\mathrm{HCO}_{3}^{-}\right]$is also regulated by the diffusion of $\mathrm{CO}_{2}$, but the significance of such a regulatory pathway is still unclear (Carlson et al. 2007) since Cah4-KO male mice remain fertile (Shah et al. 2005).

SAC is now well established as a bicarbonate chemosensor for immature and mature spermatozoa. In vivo bicarbonate modulates the enzymatic activity of sAC directly to produce cAMP under $\mathrm{pH}$-independent conditions (Chen et al. 2000). A high concentration of bicarbonate should thus be associated with high cAMP production and the reverse. However, the relationship between bicarbonate and SAC activity has not been elucidated for immature sperm. Indeed, for testicular sperm and for spermatozoa from the initial part of the epididymis, the luminal $\mathrm{HCO}_{3}^{-}$concentration is the highest and therefore the (cAMP) level is predicted to be high also, but in fact all the values available are the opposite. Furthermore, the presence of $25 \mathrm{mM}$ bicarbonate has been shown to stimulate the cAMP content of cauda spermatozoa more than the caput content (Baker et al. 2003). Therefore, the luminal bicarbonate concentration affects the activity of the sperm sAC, but a high concentration of bicarbonate is not always associated with high intracellular cAMP content in vivo and an increase in bicarbonate content in vitro does not initiate the motility of caput spermatozoa.

Low levels of extra- and intracellular bicarbonate in the epididymis in mature sperm reduce SAC activity, and consequently the intracellular cAMP levels, and maintain the sperm in a quiescent state during transit and storage in vivo (Jones \& Murdoch 1996). An increase in bicarbonate concentration activates SAC in a few minutes in a $\mathrm{pH}$-independent manner for mature sperm (Chen et al. 2000) and rapidly reverses the motility quiescence (Okamura et al. 1985), accelerating flagella beat frequency (Wennemuth et al. $2003 \mathrm{~b}$ ) and changing the membrane characteristics (Gadella \& Harrison 2002).

\section{Role of luminal calcium in epididymal spermatozoa motility}

The concentration of $\mathrm{Ca}^{2+}$ is another important factor in the control of epididymal sperm motility through the regulation of sAC (Morton et al. 1974, Armstrong et al. 1994) and through other calcium pathways independent of cAMP and PKA such as the calmodulin (CaM) pathway (Jaiswal \& Conti 2003).

Significant luminal variations in $\mathrm{Ca}^{2+}$ concentrations surround spermatozoa during epididymal transit. Between the caput and the distal cauda epididymis, free luminal ionic calcium concentration decreases from 0.8 to $0.25 \mathrm{mM}$ in the rat epididymis (Jenkins et al. 1980). The luminal $\mathrm{Ca}^{2+}$ ion is mostly absorbed by the epithelium TRPV6 channel, with the $\mathrm{Ca}^{2+}$ concentration being increased tenfold in the caudal epididymal fluid when the Trpv6 gene is deleted (Weissgerber et al. 2012).

Cellular calcium levels have been reported to be six times higher in caput spermatozoa than in caudal spermatozoa, and the rate of calcium uptake in caput spermatozoa to be about two to three times higher than that in caudal spermatozoa (Vijayaraghavan et al. 1989, White \& Aitken 1989). The high calcium concentration in caput spermatozoa could be linked to a higher rate of mitochondrial calcium accumulation in caput sperm than in caudal sperm (Vijayaraghavan et al. 1989), to the presence of the cytoplasmic droplet, which possesses relatively high levels of calcium, and also to the immaturity of the calcium regulatory pathways (Okamura et al. 1992).

The low retention of intracellular calcium by the sperm is controlled by at least two $\mathrm{Ca}^{2+}$-ATPases (Wennemuth et al. 2003a). The first, ATP2A (SERCA)1-3, a sarcoplasmic/endoplasmic reticulum $\mathrm{Ca}^{2+}$-ATPase, sequestrates calcium in the acrosome, mitochondria, and probably also in the cytoplasmic droplet. The other, ATP2B1-4, a plasma membrane $\mathrm{Ca}^{2+}$-ATPase, is the most active in $\mathrm{Ca}^{2+}$ clearance, exporting $\mathrm{Ca}^{2+}$ outside the gamete and mainly located on the membrane of the proximal principal piece of the flagellum. The activity of this $\mathrm{Ca}^{2+}$-ATPase pump increases significantly from the caput sperm to the epididymal cauda sperm (Sanchez-Luengo et al. 2004). The transfer of epididymal $\mathrm{Ca}^{2+}$-ATPase isoform 4 (PMCA4a) from the apical membrane of the cauda epididymal epithelium to the sperm membrane has recently been reported to be associated with the low $\mathrm{Ca}^{2+}$ concentration in cauda sperm (Brandenburger et al. 2011).

Several constitutive channels have been evidenced for cellular $\mathrm{Ca}^{2+}$ entry (see review by Darszon et al. (2006)) such as voltage-gated $\mathrm{Ca}^{2+}$ channels (CaVs; Benoff et al. 2007) and sperm-specific cation channels known as CatSper (CatSper1-4 and CatSper $\beta$, CatSper $\gamma \delta$ and CatSper $\gamma$ ) (Quill et al. 2001, Ren et al. 2001, Lobley et al. 2003, Wang et al. 2009, Chung et al. 2011).

The role of $\mathrm{Ca}^{2+}$ in the maturation of sperm motility in the epididymis is unclear. In vitro, physiological $\left[\mathrm{Ca}^{2+}\right]$ directly activates SAC and increases (CAMP) production by mature sperm (epididymal or ejaculated) independently of CaM binding to SAC (Jaiswal \& Conti 2003). Furthermore, an additive effect of $\mathrm{HCO}_{3}^{-}$and $\mathrm{Ca}^{2+}$ on sAC activity has also been observed on mature epididymal sperm (Jaiswal \& Conti 2003). The influx of $\mathrm{Ca}^{2+}$ is required to activate motility in most caudal epididymal sperm samples. This $\mathrm{Ca}^{2+}$ entry is not immediately linked to the CatSper channel, since the deletion of any genes of CatSper isoforms does not prevent the activation of quiescent epididymal sperm (Ren et al. 2001, Quill et al. 2006).

Calcium combined with $\mathrm{HCO}_{3}^{-}$ions is able to speed up the flagellar beating of mature sperm in vitro 
(Carlson et al. 2007) and to change the symmetrical flagellar wave propagation, according to the level of internal $\left[\mathrm{Ca}^{2+}\right]$ (Lindemann et al. 1991). On the other hand, the removal of $\mathrm{Ca}^{2+}$ prevents this speeding up of flagellar beating (Carlson et al. 2003). The low concentration of luminal and intracellular sperm $\left[\mathrm{Ca}^{2+}\right]$ in the terminal part of the epididymis thus contributes to the maintenance of sperm motility quiescent for mature epididymal sperm.

The action of $\mathrm{Ca}^{2+}$ is more complex for immature sperm. As for $\left[\mathrm{HCO}_{3}^{-}\right]$, high $\left[\mathrm{Ca}^{2+}\right]$ content in the anterior part of the epididymis is expected to activate SAC and consequently CAMP and flagellar activity, but such activation has never been described. However, the calcium concentration gradient in the luminal fluid seems to be important. After the deletion of the TRPV6 calcium channel, which prevents absorption of luminal $\mathrm{Ca}^{2+}$, the motility of mature caudal sperm cannot be normally activated (Weissgerber et al. 2012). Recently, several $\beta$-defensins (Supplementary Table 1) specifically secreted in epididymal caput have been shown to be associated with the activation of $\mathrm{Ca}^{2+}$ channels and initiation of motility of immature spermatozoa in vitro (Zhou et al. 2004).

For these immature spermatozoa, the progressive decrease in $\left[\mathrm{Ca}^{2+}\right]$ concentration during epididymal maturation and appropriate regulation of intraluminal $\mathrm{Ca}^{2+}$ concentration by the epididymal epithelium are thus essential for the establishment of potential sperm motility, but the exact effect of such changes in $\mathrm{Ca}^{2+}$ concentration is still unclear.

\section{Sperm protein phosphorylation during epididymal transit}

The flagellar movement is regulated by a network of kinases and phosphatases that induce numerous posttranscriptional protein modifications, mostly phosphorylations, in various compartments of the flagellum and axonema. Two signalling pathways involved in the phosphorylation of these proteins, the cAMP-PKA and calcium signalling pathways, are generally recognized to be essential for the regulation of mammalian sperm motility (Suarez et al. 1987, Ho \& Suarez 2001).

In the epididymis, the development of a CAMP-PKAdependent pathway leading to protein tyrosine phosphorylation has often been reported in concert with the sperm's ability to undergo capacitation. The increase in cAMP production induced by the spermatozoa in the epididymis is associated with the progressive development of a cAMP-PKA-dependent signalling pathway, which is parallel to the potential activation of motility (Pariset et al. 1985, Jaiswal \& Majumder 1996a, Baker et al. 2003). PKA subunits are associated with the flagella. After activation by cAMP, the PKA RII regulatory subunit transits to a specific location between the coarse fibres (Pariset et al. 1989), bound to the sperm-specific AKAP3 and/or AKAP4, the main constituents of fibrous sheath proteins of the sperm flagellum (Miki et al. 2002; see review by Luconi et al. (2011)). The free catalytic subunits of PKA induce serine/threonine (Ser/Thr) phosphorylation for several proteins including AKAPs and activate several tyrosine kinases downstream, such as ABL1 (ABL), CSK, SRC (CSRC), and TEC, and many others that remain to be identified (Battistone et al. 2013).

The rates of tyrosine phosphorylation and phosphorylated proteins appear to be different between immature and mature spermatozoa. In the rat, immature epididymal spermatozoa exhibit more tyrosine phosphorylation than mature sperm (Lewis \& Aitken 2001, Baker et al. 2003), but most of this phosphorylation is not related to cAMP or bicarbonate concentrations (Baker et al. 2003). On the other hand, in the mouse, the cAMP-dependent tyrosine phosphorylation is more active in mature epididymal sperm (Visconti et al. 1995, Ecroyd et al. 2004, Lin et al. 2006). The cAMP signal transduction pathway appears not to be fully functional in immature sperm, whatever the species differences.

The low activity of the cAMP-dependent tyrosine phosphorylation pathway in immature sperm has been attributed in part to the inhibitory effect of high levels of $\left[\mathrm{Ca}^{2+}\right]_{\mathrm{i}}$ (Ecroyd et al. 2004). However, the decreasing $\left[\mathrm{Ca}^{2+}\right]_{i}$ content in caput spermatozoa does not activate motility, although the cAMP-mediated signal transduction pathway is effectively activated (Ecroyd et al. 2004).

However, the initiation and stimulation of motility for caput epididymal spermatozoa have been shown to be induced, independently of calcium, by the inhibition of Ser/Thr-protein phosphatase I (PPI) activity (Vijayaraghavan et al. 1996). In most cells, PPI activity is controlled by the presence of specific inhibitors such as inhibitor-2 (I2), which forms a PPI-I2 complex, and by glycogen synthase kinase 3 (GSK3), which can reactivate PPI by dissociation of this complex. In epididymal sperm, the presence of twofold higher levels of PPI activity, identified as PP1 $\gamma 2$, and sixfold higher levels of GSK3 activity than in mature motile caudal sperm can be linked to the weak activity of the cAMP-mediated signal transduction pathway in immotile caput epididymal sperm (see review by Fardilha et al. (2011)).

Recent studies on the mature spermatozoa of mice (Baker et al. 2006, Krapf et al. 2010) and humans (Battistone et al. 2013) have revealed that a cSrc family kinase (SFK) induced the inactivation of Ser/Thr phosphatases and could be involved in the signalling pathways associated with sperm capacitation and also in sperm motility. This tyrosine kinase is detected in the flagellar midpiece of mature mouse sperm, but surprisingly this kinase is not present in sperm from the caput epididymis. This cSrc is incorporated into spermatozoa (Krapf et al. 2012) during their transit from the corpus to the cauda. Normal tyrosine phosphorylation is displayed in cSrc-null mice, but forward sperm motility is significantly reduced (Krapf et al. 2012). However, there are differences between mature mouse sperm 
and human sperm for such effects of SFK activity on motility (Varano et al. 2008, Krapf et al. 2010, Battistone et al. 2013). The hypothesis that this kinase is important during epididymal sperm maturation is strong, but needs further investigation.

The involvement of the 'endocannabinoid system' in the development of sperm motility in the epididymis has recently been proposed (Cobellis et al. 2010). The low levels of cAMP production induced by SAC from immature sperm may be related to the inhibitory effect on SAC exerted by the activated cannabinoid receptor CNR1 present on the sperm cell membrane. The inhibitory activity of the CNR1 receptor during epididymal transit may be induced by the decrease in 2-arachidonoylglycerol (2-AG) levels from the caput to the cauda. Such a decrease in 2-AG levels may hypothetically be associated with certain sperm membrane modifications that remain to be identified.

Another pathway, PI3K-AKT, has also been found to be involved in the phosphorylation of target proteins associated with mature sperm motility (Luconi et al. 2011, Sagare-Patil et al. 2013), but its activity during epididymal transit is yet to be demonstrated.

\section{Epididymal surroundings and sperm proteins involved in egg-binding components}

The development of sperm motility during transit in the epididymis is the first essential step for the spermatozoa to acquire fertility, but motile activated testicular spermatozoa are never fertile. The second important maturation step is the gradual acquisition of the ability to bind to the ZP and the oocyte membrane. The plasma membrane, i.e. the inner acrosomal membrane and the equatorial segment exposed to the sperm surface after the acrosome reaction, participates in interactions with the egg plasma membranes. The interactions between the male and female gametes are the result of successive sperm surface remodelling initiated in the testis, during epididymal transit and ending in the female tract after capacitation. The sperm plasma membrane proteins involved in ZP binding have been the most studied ones.

Different types of methodologies have been used to identify sperm and epididymal proteins involved in sperm-egg membrane interactions. Most of them have been developed using specific sperm antibodies (competitor or inhibitor) to prevent the binding of a candidate protein to the ZP or oocyte membrane. More global approaches have also been developed such as phage display technology (Naz 2005, Samoylova et al. 2012), and the ZP affinity properties of sperm proteins have been analysed using different global and selective proteomic approaches (Stein et al. 2006, Brewis \& Gadella 2010, Belleannee et al. 2011a, Guyonnet et al. 2012, Petit et al. 2013). Many protein candidates have been proposed following these in vitro studies, and more than 50 proteins have already been reported to be involved in sperm-egg interactions (Supplementary Table 1). However, the effective role of several of them in male fertility has not been confirmed, as no significant modification has been observed after their gene deletion. More surprising is the fact that when infertility was induced after gene $\mathrm{KO}$ for some of these proteins, sterility was found to be not linked to the lack of sperm binding to the oocyte components, as expected, but to a modification of sperm motility or to an unknown sperm surface component preventing the gamete from passing through the uterotubal junction (Supplementary Table 1). Furthermore, the gene deletion technique provided the opportunity to identify several other sperm proteins (ACE, CLG, HSPA2, PDILT or TPST2) (Supplementary Table 1) not directly involved in sperm-egg interactions, but linked to male sterility, although the sperm production, morphology and motility of the $\mathrm{KO}$ male mice were normal.

The most important role of the epididymis in the development of the sperm-egg interactions may be linked to the control of the processing and domain redistribution of several testicular sperm surface proteins, particularly for different members of the ADAM protein family (e.g. ADAM1B, ADAM2, ADAM3, ADAM5 and ADAM32) and also for other proteins such as tACE, basigin and TEX101 (Supplementary Table 1). Most of these surface changes, occurring principally in the first part of the epididymis, are linked to the local activation of proteolytic activities either on the sperm surface itself or from luminal components. However, no luminal protease activities already identified in the epididymal tubule have formally been reported to be linked to such sperm surface processes (Metayer et al. 2002). These testicular sperm surface modifications may be associated with the development of the binding properties of the spermatozoa, but synchronization between these two events during epididymal transit is not obvious. The development of egg-sperm binding may also be induced by the adsorption or fusion of several epididymal proteins to the sperm membrane (e.g. ARSA, CD52, CRISP1, CRISP4, CRISP7, DCX, EPPIN, MFGE8, SPAM1 and SPINK13). The contribution of each of these epididymal proteins to the egg-binding properties of mature epididymal sperm is difficult to evaluate, as no gene $\mathrm{KO}$ of these proteins has induced a severe reduction in male fertility to date (Supplementary Table 1).

Nevertheless, among the many proteins reported to have binding affinity to the ZP and oocyte membrane, two appear to be more strongly associated with sperm fertility. The first, IZUMO, is a newly discovered member of the immunoglobulin superfamily but apparently not involved in the epididymal sperm maturation process, since it is detectable on the mature sperm surface only after the acrosome reaction. The complete sterility of Izumo $^{-1-}$ male mice is induced by a defect in sperm-egg fusion, although the sperm is able to bind 
to and penetrate the ZP and also to bind to the egg plasma membrane (Inoue et al. 2005). The egg partners of IZUMO and its role in the egg fusogen function remain to be determined.

The second is ADAM3 (cyritestin), a $42 \mathrm{kDa}$ surface protein of epididymal sperm resulting from the processing of a $110 \mathrm{kDa}$ testicular precursor in the first part of the epididymis. The sterility of Adam3-deficient male mice is mainly linked to a lack of sperm migration from the uterus to the oviduct. Adam $3^{-1-}$ mouse sperm have poor binding affinity to the ZP and egg plasma membrane in vitro, but are fertile after oviduct AI or IVF with cumulus-intact and ZP-intact eggs. The same phenotype of $A d a m 3^{-1-}$ male sterility is also obtained after gene $\mathrm{KO}$ for at least ten sperm proteins (i.e. ACE, CLGN, ADAM2, ADAM1A, CALR3, TPST2, PDILT, PMIS2, PRSS37, and TEX101) (Supplementary Table 1). Among all these $\mathrm{KO}$ genes in male mice, Adam3 is strongly reduced or incorrectly located on the mature epididymal sperm surface. The loss of ADAM3 from the mature sperm surface was also observed after Rnase 10 gene $\mathrm{KO}$, a protein secreted only in the initial segment of the epididymis and without any sperm membrane affinities (Krutskikh et al. 2012). Such results show that the stability, integrity, and location of ADAM3 at the sperm surface are linked to the presence and/or activities of several other proteins. In the testis, several chaperone proteins (e.g. calmegin, CALR3, and PDILT), different ADAM proteins associated in a complex with ADAM3 (ADAM1b, ADAM2 and ADAM6), and other proteins such as TPST2 and ACE (see review by Cho (2012)) are essential for the location of ADAM3 on the sperm surface. In the epididymis, the activity of unknown proteases is needed to cleave the prodomain and MMP domains of ADAM3, which is also dependent on the removal of TEX101 from the sperm surface in the epididymis (Fujihara et al. 2013).

Thus, when one or more of these essential proteins for ADAM3 are missing, all or a great number of the ADAM3 molecules (Cho 2012) are specifically removed from the sperm surface during epididymal transit by the activity of an unknown protease. Therefore, ADAM3 seems to be a key protein in male fertility, but its removal from the sperm surface only prevents the sperm from passing through the uterotubal junction but not from fertilizing cumulus-intact eggs after oviduct insemination. Furthermore, such an ADAM protein is not present in human sperm, since human $A D A M 3$ genes are not found to be functional (Grzmil 2001).

The mechanisms involved in sperm-egg interactions in mammals (including humans) are still unclear. The interactions between male and female gametes appear to be more complicated than a simple ligand-receptor model. Most of the sperm proteins involved in eggmembrane interactions, such as the ADAM protein family, are present in very low quantities at the sperm surface and can only be visualized at the sperm surface by sensitive techniques such as immunodetection. Therefore, it is realistic that the binding force between the sperm and the egg generated by only one of these proteins would not be enough to maintain such an interaction in vivo. It is now accepted that more than one protein is involved and that these proteins could be combined together in a protein complex (Reid et al. 2011), potentially included in the lipid raft domains of the sperm membrane. Such a protein complex might be formed by several ADAMs and also by other known or as-yet-unknown sperm components such as HSPA2, HSPA5, ARSA, SPAM1, or CCT/TRiC complex and ITM2B, already identified as major sperm surface proteins (Belleannee et al. 2011a, Bromfield \& Nixon 2013; Fig. 2). In the epididymis, an abnormal composition of such a sperm surface complex might induce abnormal epididymal protease activity towards some of these sperm surface proteins such as ADAM3.

The identification of sperm proteins and the exact role of the epididymis in the molecular mechanisms really involved in gamete interactions is still a challenge. Despite the complexity, the role of epididymal maturation in the development and/or the control of the egg-sperm binding properties is indisputable.

\section{Conclusion}

The epididymal maturation of spermatozoa is an essential post-testicular stage in the acquisition of fertility by the male gamete. During the 1 or 2 weeks of transit of the sperm in this organ, subtle sequential changes occur successively in several subdomains of the gamete. In spite of the significant improvement in the understanding of the protein composition of the spermatozoa and the molecular mechanisms involved in both the motility process and egg binding during the last 10 years, the role of the epididymis is still not fully explained. Different signalling pathways between immature and mature spermatozoa are now well described, but their targets, such as the motility process, initiation of capacitation, or other metabolism changes, have not been fully identified. The role of the epididymal surroundings in the activation or inactivation of several of these sperm signalling pathways is undeniable, but the mechanisms by which several luminal components such as ionic components (calcium, $\mathrm{pH}$, and $\mathrm{HCO}_{3}^{-}$) exert either inhibitory or stimulatory effects according to the maturation stage of the gamete remain to be fully elucidated. Furthermore, the fact that the sperm modifications occurring during epididymal transit have a physiological effect only when the gametes are in the female tract make the in vitro evaluation of such modifications more complicated and perhaps liable to misinterpretation. This may be the case for the sperm surface proteins involved in the egg-binding components.

With the recent increase in the understanding of the protein composition of spermatozoa and the epididymal 
surroundings, it is now evident that there are considerable differences between species. The post-testicular maturation of the spermatozoon is a general process in mammals, but most of the recent results, in particular, those obtained using $\mathrm{KO}$ genes, have been obtained from rodent studies. The study of epididymal sperm maturation in other species will be an important step in the understanding of the species specificity of sperm fertility, particularly for humans.

\section{Supplementary data}

This is linked to the online version of the paper at http://dx.doi. org/10.1530/REP-13-0420.

\section{Declaration of interest}

The authors declare that there is no conflict of interest that could be perceived as prejudicing the impartiality of the review.

\section{Funding}

This research did not receive any specific grant from any funding agency in the public, commercial or not-for-profit sector.

\section{References}

Acott TS, Katz DF \& Hoskins DD 1983 Movement characteristics of bovine epididymal spermatozoa: effects of forward motility protein and epididymal maturation. Biology of Reproduction 29 389-399. (doi:10. 1095/biolreprod29.2.389)

Amaral A, Castillo J, Estanyol JM, Ballesca JL, Ramalho-Santos J \& Oliva R 2013 Human sperm tail proteome suggests new endogenous metabolic pathways. Molecular \& Cellular Proteomics 12 330-342. (doi:10.1074/ mcp.M112.020552)

Armstrong VL, Clulow J, Murdoch RN \& Jones RC 1994 Intracellular signal transduction mechanisms of rat epididymal spermatozoa and their relationship to motility and metabolism. Molecular Reproduction and Development 38 77-84. (doi:10.1002/mrd.1080380113)

Baker MA, Lewis B, Hetherington L \& Aitken RJ 2003 Development of the signalling pathways associated with sperm capacitation during epididymal maturation. Molecular Reproduction and Development 64 446-457. (doi:10.1002/mrd.10255)

Baker MA, Hetherington L \& Aitken RJ 2006 Identification of SRC as a key PKA-stimulated tyrosine kinase involved in the capacitation-associated hyperactivation of murine spermatozoa. Journal of Cell Science $\mathbf{1 1 9}$ 3182-3192. (doi:10.1242/jcs.03055)

Baker MA, Hetherington L, Reeves G, Muller J \& Aitken RJ 2008a The rat sperm proteome characterized via IPG strip prefractionation and LC-MS/MS identification. Proteomics 8 2312-2321. (doi:10.1002/ pmic.200700876)

Baker MA, Hetherington L, Reeves GM \& Aitken RJ 2008b The mouse sperm proteome characterized via IPG strip prefractionation and LC-MS/MS identification. Proteomics 8 1720-1730. (doi:10.1002/ pmic.200701020)

Baker MA, Hetherington L, Weinberg A, Naumovski N, Velkov T, Pelzing M, Dolman S, Condina MR \& Aitken RJ 2012 Analysis of phosphopeptide changes as spermatozoa acquire functional competence in the epididymis demonstrates changes in the post-translational modification of Izumo1. Journal of Proteome Research 11 5252-5264. (doi:10.1021/pr300468m)
Baker MA, Naumovski N, Hetherington L, Weinberg A, Velkov T \& Aitken RJ 2013 Head and flagella subcompartmental proteomic analysis of human spermatozoa. Proteomics 13 61-74. (doi:10.1002/pmic. 201200350)

Battistone MA, Da Ros VG, Salicioni AM, Navarrete FA, Krapf D, Visconti PE \& Cuasnicu PS 2013 Functional human sperm capacitation requires both bicarbonate-dependent PKA activation and downregulation of Ser/Thr phosphatases by Src family kinases. Molecular Human Reproduction 19 570-580. (doi:10.1093/molehr/gat033)

Belleannee C, Belghazi M, Labas V, Teixeira-Gomes AP, Gatti JL, Dacheux JL \& Dacheux F 2011a Purification and identification of sperm surface proteins and changes during epididymal maturation. Proteomics 11 1952-1964. (doi:10.1002/pmic.201000662)

Belleannee C, Labas V, Teixeira-Gomes AP, Gatti JL, Dacheux JL \& Dacheux F 2011b Identification of luminal and secreted proteins in bull epididymis. Journal of Proteomics 74 59-78. (doi:10.1016/j.jprot.2010. 07.013)

Benoff S, Chu CC, Marmar JL, Sokol RZ, Goodwin LO \& Hurley IR 2007 Voltage-dependent calcium channels in mammalian spermatozoa revisited. Frontiers in Bioscience 12 1420-1449. (doi:10.2741/2158)

Bork K, Chevrier C, Paquignon M, Jouannet P \& Dacheux JL 1988 Flagellar motility and movement of boar spermatozoa during epididymal transit. Reproduction, Nutrition, Development 28 1307-1315. (doi:10.1051/ rnd:19880811)

Brandenburger T, Strehler EE, Filoteo AG, Caride AJ, Aumuller G, Post H, Schwarz A \& Wilhelm B 2011 Switch of PMCA4 splice variants in bovine epididymis results in altered isoform expression during functional sperm maturation. Journal of Biological Chemistry 286 7938-7946. (doi:10. 1074/jbc.M110.142836)

Breton S 2001 The cellular physiology of carbonic anhydrases. Journal of the Pancreas 2 159-164.

Brewis IA \& Gadella BM 2010 Sperm surface proteomics: from protein lists to biological function. Molecular Human Reproduction 16 68-79. (doi:10.1093/molehr/gap077)

Bromfield EG \& Nixon B 2013 The function of chaperone proteins in the assemblage of protein complexes involved in gamete adhesion and fusion processes. Reproduction 145 R31-R42. (doi:10.1530/REP-12-0316)

Brooks DE 1981 Secretion of proteins and glycoproteins by the rat epididymis: regional differences, androgen-dependence, and effects of protease inhibitors, procaine, and tunicamycin. Biology of Reproduction 25 1099-1117. (doi:10.1095/biolreprod25.5.1099)

Buck J, Sinclair ML, Schapal L, Cann MJ \& Levin LR 1999 Cytosolic adenylyl cyclase defines a unique signaling molecule in mammals. PNAS 96 79-84. (doi:10.1073/pnas.96.1.79)

Cao W, Gerton GL \& Moss SB 2006 Proteomic profiling of accessory structures from the mouse sperm flagellum. Molecular \& Cellular Proteomics 5 801-810. (doi:10.1074/mcp.M500322-MCP200)

Carlson AE, Westenbroek RE, Quill T, Ren D, Clapham DE, Hille B, Garbers DL \& Babcock DF 2003 CatSper1 required for evoked $\mathrm{Ca}^{2+}$ entry and control of flagellar function in sperm. PNAS 100 14864-14868. (doi:10.1073/pnas.2536658100)

Carlson AE, Hille B \& Babcock DF 2007 External $\mathrm{Ca}^{2+}$ acts upstream of adenylyl cyclase SACY in the bicarbonate signaled activation of sperm motility. Developmental Biology 312 183-192. (doi:10.1016/j.ydbio. 2007.09.017)

Castella S, Fouchecourt S, Teixeira-Gomes AP, Vinh J, Belghazi M, Dacheux F \& Dacheux JL 2004 Identification of a member of a new RNase a family specifically secreted by epididymal caput epithelium. Biology of Reproduction 70 319-328. (doi:10.1095/biolreprod.103. 022459)

Chabory E, Damon C, Lenoir A, Henry-Berger J, Vernet P, Cadet R, Saez F \& Drevet JR 2010 Mammalian glutathione peroxidases control acquisition and maintenance of spermatozoa integrity. Journal of Animal Science $\mathbf{8 8}$ 1321-1331. (doi:10.2527/jas.2009-2583)

Chan CC, Shui HA, Wu CH, Wang CY, Sun GH, Chen HM \& Wu GJ 2009 Motility and protein phosphorylation in healthy and asthenozoospermic sperm. Journal of Proteome Research 8 5382-5386. (doi:10.1021/ pr9003932)

Chauvin T, Xie F, Liu T, Nicora CD, Yang F, Camp DG II, Smith RD \& Roberts KP 2012 A systematic analysis of a deep mouse epididymal sperm proteome. Biology of Reproduction 87 141. (doi:10.1095/ biolreprod.112.104208) 
Chen Y, Cann MJ, Litvin TN, lourgenko V, Sinclair ML, Levin LR \& Buck J 2000 Soluble adenylyl cyclase as an evolutionarily conserved bicarbonate sensor. Science 289 625-628. (doi:10.1126/science.289.5479.625)

Chevrier C \& Dacheux JL 1992 Evolution of the flagellar waveform of ram spermatozoa in relation to the degree of epididymal maturation. Cell Motility and the Cytoskeleton 23 8-18. (doi:10.1002/cm.970230103)

Cho C 2012 Testicular and epididymal ADAMs: expression and function during fertilization. Nature Reviews. Urology 9 550-560. (doi:10.1038/ nrurol.2012.167)

Chung JJ, Navarro B, Krapivinsky G, Krapivinsky L \& Clapham DE 2011 A novel gene required for male fertility and functional CATSPER channel formation in spermatozoa. Nature Communications 2 153. (doi:10.1038/ ncomms1153)

Cobellis G, Ricci G, Cacciola G, Orlando P, Petrosino S, Cascio MG, Bisogno T, De Petrocellis L, Chioccarelli T, Altucci L et al. 2010 A gradient of 2-arachidonoylglycerol regulates mouse epididymal sperm cell start-up. Biology of Reproduction 82 451-458. (doi:10.1095/ biolreprod.109.079210)

Cooper TG 2005 Cytoplasmic droplets: the good, the bad or just confusing? Human Reproduction 20 9-11. (doi:10.1093/humrep/deh555)

Dacheux JL \& Paquignon M 1980 Relations between the fertilizing ability, motility and metabolism of epididymal spermatozoa. Reproduction, Nutrition, Development 20 1085-1099. (doi:10.1051/rnd:19800617)

Dacheux JL \& Voglmayr JK 1983 Sequence of sperm cell surface differentiation and its relationship to exogenous fluid proteins in the ram epididymis. Biology of Reproduction 29 1033-1046. (doi:10.1095/ biolreprod29.4.1033)

Dacheux JL, O'Shea T \& Paquignon M 1979 Effects of osmolality, bicarbonate and buffer on the metabolism and motility of testicular, epididymal and ejaculated spermatozoa of boars. Journal of Reproduction and Fertility 55 287-296. (doi:10.1530/jrf.0.0550287)

Dacheux JL, Belghazi M, Lanson Y \& Dacheux F 2006 Human epididymal secretome and proteome. Molecular and Cellular Endocrinology 250 36-42. (doi:10.1016/j.mce.2005.12.022)

Dacheux JL, Dacheux F, Labas V, Ecroyd H, Nixon B \& Jones RC 2009 New proteins identified in epididymal fluid from the platypus (Ornithorhynchus anatinus). Reproduction, Fertility, and Development 21 1002-1007. (doi:10.1071/RD09091)

Dacheux JL, Belleannee C, Guyonnet B, Labas V, Teixeira-Gomes AP, Ecroyd H, Druart X, Gatti JL \& Dacheux F 2012 The contribution of proteomics to understanding epididymal maturation of mammalian spermatozoa. Systems Biology in Reproductive Medicine 58 197-210. (doi:10.3109/19396368.2012.663233)

Darszon A, Acevedo JJ, Galindo BE, Hernandez-Gonzalez EO, Nishigaki T, Trevino CL, Wood C \& Beltran C 2006 Sperm channel diversity and functional multiplicity. Reproduction 131 977-988. (doi:10.1530/ rep.1.00612)

Da Silva N, Pietrement C, Brown D \& Breton S 2006 Segmental and cellular expression of aquaporins in the male excurrent duct. Biochimica et Biophysica Acta 1758 1025-1033. (doi:10.1016/ j.bbamem.2006.06.026)

Ecroyd H, Asquith KL, Jones RC \& Aitken RJ 2004 The development of signal transduction pathways during epididymal maturation is calcium dependent. Developmental Biology 268 53-63. (doi:10.1016/j.ydbio. 2003.12.015)

Ecroyd H, Belghazi M, Dacheux JL \& Gatti JL 2005 The epididymal soluble prion protein forms a high-molecular-mass complex in association with hydrophobic proteins. Biochemical Journal 392 211-219. (doi:10.1042/ BJ20050459)

Ekstedt E, Holm L \& Ridderstrale Y 2004 Carbonic anhydrase in mouse testis and epididymis; transfer of isozyme IV to spermatozoa during passage. Journal of Molecular Histology 35 167-173. (doi:10.1023/ B:HIJO.0000023387.02793.af)

Esposito G, Jaiswal BS, Xie F, Krajnc-Franken MA, Robben TJ, Strik AM, Kuil C, Philipsen RL, van Duin M, Conti M et al. 2004 Mice deficient for soluble adenylyl cyclase are infertile because of a severe sperm-motility defect. PNAS 101 2993-2998. (doi:10.1073/pnas.0400050101)

Fabrega A, Puigmule M, Dacheux JL, Bonet S \& Pinart E 2012 Glycocalyx characterisation and glycoprotein expression of Sus domesticus epididymal sperm surface samples. Reproduction, Fertility, and Development 24 619-630. (doi:10.1071/RD11064)
Fardilha M, Esteves SL, Korrodi-Gregorio L, Pelech S, da Cruz ESOA \& da Cruz ESE 2011 Protein phosphatase 1 complexes modulate sperm motility and present novel targets for male infertility. Molecular Human Reproduction 17 466-477. (doi:10.1093/molehr/gar004)

Ficarro S, Chertihin O, Westbrook VA, White F, Jayes F, Kalab P, Marto JA, Shabanowitz J, Herr JC, Hunt DF et al. 2003 Phosphoproteome analysis of capacitated human sperm. Evidence of tyrosine phosphorylation of a kinase-anchoring protein 3 and valosin-containing protein/p97 during capacitation. Journal of Biological Chemistry 278 11579-11589. (doi:10.1074/jbc.M202325200)

Fouchecourt S, Metayer S, Locatelli A, Dacheux F \& Dacheux JL 2000 Stallion epididymal fluid proteome: qualitative and quantitative characterization; secretion and dynamic changes of major proteins. Biology of Reproduction 62 1790-1803. (doi:10.1095/biolreprod62.6.1790)

Fouchecourt S, Charpigny G, Reinaud P, Dumont P \& Dacheux JL 2002 Mammalian lipocalin-type prostaglandin D2 synthase in the fluids of the male genital tract: putative biochemical and physiological functions. Biology of Reproduction 66 458-467. (doi:10.1095/biolreprod66.2.458)

Frenette G, Lessard C \& Sullivan R 2002 Selected proteins of "prostasomelike particles" from epididymal cauda fluid are transferred to epididymal caput spermatozoa in bull. Biology of Reproduction 67 308-313. (doi:10.1095/biolreprod67.1.308)

Fritz IB, Burdzy K, Setchell B \& Blaschuk O 1983 Ram rete testis fluid contains a protein (clusterin) which influences cell-cell interactions in vitro. Biology of Reproduction 28 1173-1188. (doi:10.1095/ biolreprod28.5.1173)

Fujihara Y, Tokuhiro K, Muro Y, Kondoh G, Araki Y, Ikawa M \& Okabe M 2013 Expression of TEX101, regulated by ACE, is essential for the production of fertile mouse spermatozoa. PNAS 110 8111-8116. (doi:10.1073/pnas.1222166110)

Gadella BM \& Harrison RA 2002 Capacitation induces cyclic adenosine 3', 5'-monophosphate-dependent, but apoptosis-unrelated, exposure of aminophospholipids at the apical head plasma membrane of boar sperm cells. Biology of Reproduction 67 340-350. (doi:10.1095/ biolreprod67.1.340)

Gatti JL, Druart X, Guerin Y, Dacheux F \& Dacheux JL 1999 A 105- to 94-kilodalton protein in the epididymal fluids of domestic mammals is angiotensin I-converting enzyme (ACE); evidence that sperm are the source of this ACE. Biology of Reproduction 60 937-945. (doi:10.1095/ biolreprod60.4.937)

Gatti JL, Druart X, Syntin P, Guerin Y, Dacheux JL \& Dacheux F 2000 Biochemical characterization of two ram cauda epididymal maturationdependent sperm glycoproteins. Biology of Reproduction 62 950-958. (doi:10.1095/biolreprod62.4.950)

Gatti JL, Metayer S, Moudjou M, Andreoletti O, Lantier F, Dacheux JL \& Sarradin P 2002 Prion protein is secreted in soluble forms in the epididymal fluid and proteolytically processed and transported in seminal plasma. Biology of Reproduction 67 393-400. (doi:10.1095/ biolreprod67.2.393)

Gatti JL, Metayer S, Belghazi M, Dacheux F \& Dacheux JL 2005 Identification, proteomic profiling, and origin of ram epididymal fluid exosome-like vesicles. Biology of Reproduction 72 1452-1465. (doi:10. 1095/biolreprod.104.036426)

Grzmil P 2001 Human cyritestin genes (CYRN1 and CYRN2) are nonfunctional. Biochemical Journal 357 551-556. (doi:10.1042/02646021:3570551)

Guo W, Qu F, Xia L, Guo Q, Ying X \& Ding Z 2007 Identification and characterization of ERp29 in rat spermatozoa during epididymal transit. Reproduction 133 575-584. (doi:10.1530/REP-06-0301)

Guyonnet B, Dacheux F, Dacheux JL \& Gatti JL 2011 The epididymal transcriptome and proteome provide some insights into new epididymal regulations. Journal of Andrology 32 651-664. (doi:10.2164/jandrol. 111.013086)

Guyonnet B, Zabet-Moghaddam M, SanFrancisco S \& Cornwall GA 2012 Isolation and proteomic characterization of the mouse sperm acrosomal matrix. Molecular \& Cellular Proteomics 11 758-774. (doi:10.1074/ mcp.M112.020339)

Hermo L \& Jacks D 2002 Nature's ingenuity: bypassing the classical secretory route via apocrine secretion. Molecular Reproduction and Development 63 394-410. (doi:10.1002/mrd.90023) 
Hermo L, Chong DL, Moffatt P, Sly WS, Waheed A \& Smith CE 2005 Regionand cell-specific differences in the distribution of carbonic anhydrases II, III, XII, and XIV in the adult rat epididymis. Journal of Histochemistry and Cytochemistry 53 699-713. (doi:10.1369/jhc.4A6575.2005)

Hess KC, Jones BH, Marquez B, Chen Y, Ord TS, Kamenetsky M, Miyamoto C, Zippin JH, Kopf GS, Suarez SS et al. 2005 The "soluble" adenylyl cyclase in sperm mediates multiple signaling events required for fertilization. Developmental Cell 9 249-259. (doi:10.1016/j.devcel. 2005.06.007)

Ho HC \& Suarez SS 2001 Hyperactivation of mammalian spermatozoa: function and regulation. Reproduction 122 519-526. (doi:10.1530/rep. $0.1220519)$

Hoskins DD, Stephens DT \& Hall ML 1974 Cyclic adenosine $3^{\prime}: 5^{\prime}$-monophosphate and protein kinase levels in developing bovine spermatozoa. Journal of Reproduction and Fertility 37 131-133. (doi:10.1530/jrf.0.0370131)

Ijiri TW, Merdiushev T, Cao W \& Gerton GL 2011 Identification and validation of mouse sperm proteins correlated with epididymal maturation. Proteomics 11 4047-4062. (doi:10.1002/pmic.201100075)

Ilio KY \& Hess RA 1994 Structure and function of the ductuli efferentes: a review. Microscopic Research and Technique 29 432-467. (doi:10. 1002/jemt.1070290604)

Inoue N, Ikawa M, Isotani A \& Okabe M 2005 The immunoglobulin superfamily protein Izumo is required for sperm to fuse with eggs. Nature 434 234-238. (doi:10.1038/nature03362)

Inskeep PB \& Hammerstedt RH 1982 Changes in metabolism of ram sperm associated with epididymal transit or induced by exogenous carnitine. Biology of Reproduction 27 735-743. (doi:10.1095/biolreprod27.3.735)

Ishijima S \& Witman GB 1991 Demembranation and reactivation of mammalian spermatozoa from golden hamster and ram. Methods in Enzymology 196 417-428.

Jaiswal BS \& Conti M 2003 Calcium regulation of the soluble adenylyl cyclase expressed in mammalian spermatozoa. PNAS $\mathbf{1 0 0}$ 10676-10681. (doi:10.1073/pnas.1831008100)

Jaiswal BS \& Majumder GC 1996a Cyclic AMP phosphodiesterase: a regulator of forward motility initiation during epididymal sperm maturation. Biochemistry and Cell Biology 74 669-674. (doi:10.1139/o96-072)

Jaiswal BS \& Majumder GC $1996 b$ In-vitro initiation of forward motility in testicular spermatozoa. International Journal of Andrology 19 97-102. (doi:10.1111/j.1365-2605.1996.tb00443.x)

Jenkins AD, Lechene CP \& Howards SS 1980 Concentrations of seven elements in the intraluminal fluids of the rat seminiferous tubules, rate testis, and epididymis. Biology of Reproduction 23 981-987.

Johnston DS, Wooters J, Kopf GS, Qiu Y \& Roberts KP 2005 Analysis of the human sperm proteome. Annals of the New York Academy of Sciences 1061 190-202. (doi:10.1196/annals.1336.021)

Jones RC \& Murdoch RN 1996 Regulation of the motility and metabolism of spermatozoa for storage in the epididymis of eutherian and marsupial mammals. Reproduction, Fertility, and Development 8 553-568. (doi:10.1071/RD9960553)

Kameshwari DB, Bhande S, Sundaram CS, Kota V, Siva AB \& Shivaji S 2010 Glucose-regulated protein precursor (GRP78) and tumor rejection antigen (GP96) are unique to hamster caput epididymal spermatozoa. Asian Journal of Andrology 12 344-355. (doi:10.1038/aja.2010.19)

Kirchhoff C 1996 CD52 is the 'major maturation-associated' sperm membrane antigen. Molecular Human Reproduction 2 9-17. (doi:10.1093/ molehr/2.1.9)

Krapf D, Arcelay E, Wertheimer EV, Sanjay A, Pilder SH, Salicioni AM \& Visconti PE 2010 Inhibition of Ser/Thr phosphatases induces capacitation-associated signaling in the presence of Src kinase inhibitors. Journal of Biological Chemistry 285 7977-7985. (doi:10.1074/ jbc.M109.085845)

Krapf D, Ruan YC, Wertheimer EV, Battistone MA, Pawlak JB, Sanjay A, Pilder SH, Cuasnicu P, Breton S \& Visconti PE 2012 cSrc is necessary for epididymal development and is incorporated into sperm during epididymal transit. Developmental Biology 369 43-53. (doi:10.1016/ j.ydbio.2012.06.017)

Krutskikh A, Poliandri A, Cabrera-Sharp V, Dacheux JL, Poutanen M \& Huhtaniemi I 2012 Epididymal protein Rnase10 is required for posttesticular sperm maturation and male fertility. FASEB Journal 26 4198-4209. (doi:10.1096/fj.12-205211)
Levine N \& Marsh DJ 1971 Micropuncture studies of the electrochemical aspects of fluid and electrolyte transport in individual seminiferous tubules, the epididymis and the vas deferens in rats. Journal of Physiology 213 557-570.

Lewis B \& Aitken RJ 2001 Impact of epididymal maturation on the tyrosine phosphorylation patterns exhibited by rat spermatozoa. Biology of Reproduction 64 1545-1556. (doi:10.1095/biolreprod64.5.1545)

Lin M, Lee YH, Xu W, Baker MA \& Aitken RJ 2006 Ontogeny of tyrosine phosphorylation-signaling pathways during spermatogenesis and epididymal maturation in the mouse. Biology of Reproduction 75 588-597. (doi:10.1095/biolreprod.106.052712)

Lindemann CB, Gardner TK, Westbrook E \& Kanous KS 1991 The calciuminduced curvature reversal of rat sperm is potentiated by CAMP and inhibited by anti-calmodulin. Cell Motility and the Cytoskeleton 20 316-324. (doi:10.1002/cm.970200407)

Liu Y, Wang DK \& Chen LM 2012 The physiology of bicarbonate transporters in mammalian reproduction. Biology of Reproduction $\mathbf{8 6}$ 99. (doi:10.1095/biolreprod.111.096826)

Lobley A, Pierron V, Reynolds L, Allen L \& Michalovich D 2003 Identification of human and mouse CatSper3 and CatSper4 genes: characterisation of a common interaction domain and evidence for expression in testis. Reproductive Biology and Endocrinology 153. (doi:10.1186/1477-7827-1-53)

Luconi M, Cantini G, Baldi E \& Forti G 2011 Role of a-kinase anchoring proteins (AKAPs) in reproduction. Frontiers in Bioscience 16 1315-1330. (doi:10.2741/3791)

Martinez-Heredia J, de Mateo S, Vidal-Taboada JM, Ballesca JL \& Oliva R 2008 Identification of proteomic differences in asthenozoospermic sperm samples. Human Reproduction 23 783-791. (doi:10.1093/ humrep/den024)

Metayer S, Dacheux F, Dacheux JL \& Gatti JL 2002 Comparison, characterization, and identification of proteases and protease inhibitors in epididymal fluids of domestic mammals. Matrix metalloproteinases are major fluid gelatinases. Biology of Reproduction 66 1219-1229. (doi:10.1095/biolreprod66.5.1219)

Miki K, Willis WD, Brown PR, Goulding EH, Fulcher KD \& Eddy EM 2002 Targeted disruption of the Akap4 gene causes defects in sperm flagellum and motility. Developmental Biology 248 331-342. (doi:10.1006/dbio. 2002.0728)

Morisawa M 1994 Cell signaling mechanisms for sperm motility. Zoological Science 11 647-662.

Morton B, Harrigan-Lum J, Albagli L \& Jooss T 1974 The activation of motility in quiescent hamster sperm from the epididymis by calcium and cyclic nucleotides. Biochemical and Biophysical Research Communications 56 372-379. (doi:10.1016/0006-291X(74)90852-3)

Naz RK 2005 Search for peptide sequences involved in human antisperm antibody-mediated male immunoinfertility by using phage display technology. Molecular Reproduction and Development 72 25-30. (doi:10.1002/mrd.20315)

Nixon B, Bielanowicz A, McLaughlin EA, Tanphaichitr N, Ensslin MA \& Aitken RJ 2009 Composition and significance of detergent resistant membranes in mouse spermatozoa. Journal of Cellular Physiology $\mathbf{2 1 8}$ 122-134. (doi:10.1002/jcp.21575)

Okamura N, Tajima Y, Soejima A, Masuda H \& Sugita Y 1985 Sodium bicarbonate in seminal plasma stimulates the motility of mammalian spermatozoa through direct activation of adenylate cyclase. Journal of Biological Chemistry 260 9699-9705.

Okamura N, Tajima Y \& Sugita Y 1988 Decrease in bicarbonate transport activities during epididymal maturation of porcine sperm. Biochemical and Biophysical Research Communications 157 1280-1287. (doi:10. 1016/S0006-291X(88)81013-1)

Okamura N, Onoe S, Sugita Y, Paquignon M, Dacheux F \& Dacheux JL 1991 Water insoluble fraction of egg yolk maintains porcine sperm motility by activating adenylate cyclase. Molecular Reproduction and Development 28 136-142. (doi:10.1002/mrd.1080280206)

Okamura N, Fukuda A, Tanba M, Sugita Y \& Nagai T 1992 Changes in the nature of calcium transport systems on the porcine sperm plasma membrane during epididymal maturation. Biochimica et Biophysica Acta 1108 110-114. (doi:10.1016/0005-2736(92)90120-B)

Oliva R, de Mateo S \& Estanyol JM 2009 Sperm cell proteomics. Proteomics 9 1004-1017. (doi:10.1002/pmic.200800588) 
Pariset CC, Feinberg JM, Dacheux JL \& Weinman SJ 1985 Changes in calmodulin level and cAMP-dependent protein kinase activity during epididymal maturation of ram spermatozoa. Journal of Reproduction and Fertility 74 105-112. (doi:10.1530/jrf.0.0740105)

Pariset C, Feinberg J, Dacheux JL, Oyen O, Jahnsen T \& Weinman S 1989 Differential expression and subcellular localization for subunits of cAMP-dependent protein kinase during ram spermatogenesis. Journal of Cell Biology 109 1195-1205. (doi:10.1083/jcb.109.3.1195)

Park K, Jeon S, Song YJ \& Yi LS 2012 Proteomic analysis of boar spermatozoa and quantity changes of superoxide dismutase 1 , glutathione peroxidase, and peroxiredoxin 5 during epididymal maturation. Animal Reproduction Science 135 53-61. (doi:10.1016/j. anireprosci.2012.08.027)

Patil SB, Kulanand J, Padma P \& Shivaji S 2002 Reactivation of motility of demembranated hamster spermatozoa: role of protein tyrosine kinase and protein phosphatases. Andrologia 34 74-86. (doi:10.1046/j.03034569.2001.00474.x)

Peddinti D, Nanduri B, Kaya A, Feugang JM, Burgess SC \& Memili E 2008 Comprehensive proteomic analysis of bovine spermatozoa of varying fertility rates and identification of biomarkers associated with fertility. BMC Systems Biology 2 19. (doi:10.1186/1752-0509-2-19)

Petit FM, Serres C, Bourgeon F, Pineau C \& Auer J 2013 Identification of sperm head proteins involved in zona pellucida binding. Human Reproduction 28 852-865. (doi:10.1093/humrep/des452)

Platt MD, Salicioni AM, Hunt DF \& Visconti PE 2009 Use of differential isotopic labeling and mass spectrometry to analyze capacitationassociated changes in the phosphorylation status of mouse sperm proteins. Journal of Proteome Research 8 1431-1440. (doi:10.1021/ pr800796j)

Quill TA, Ren D, Clapham DE \& Garbers DL 2001 A voltage-gated ion channel expressed specifically in spermatozoa. PNAS 98 12527-12531. (doi:10.1073/pnas.221454998)

Quill TA, Wang D \& Garbers DL 2006 Insights into sperm cell motility signaling through sNHE and the CatSpers. Molecular and Cellular Endocrinology 250 84-92. (doi:10.1016/j.mce.2005.12.031)

Reid AT, Redgrove K, Aitken RJ \& Nixon B 2011 Cellular mechanisms regulating sperm-zona pellucida interaction. Asian Journal of Andrology 13 88-96. (doi:10.1038/aja.2010.74)

Ren D, Navarro B, Perez G, Jackson AC, Hsu S, Shi Q, Tilly JL \& Clapham DE 2001 A sperm ion channel required for sperm motility and male fertility. Nature 413 603-609. (doi:10.1038/35098027)

Sagare-Patil V, Vernekar M, Galvankar M \& Modi D 2013 Progesterone utilizes the PI3K-AKT pathway in human spermatozoa to regulate motility and hyperactivation but not acrosome reaction. Molecular and Cellular Endocrinology 374 82-91. (doi:10.1016/j.mce. 2013.04.005)

Samoylova TI, Cochran AM, Samoylov AM, Schemera B, Breiteneicher AH, Ditchkoff SS, Petrenko VA \& Cox NR 2012 Phage display allows identification of zona pellucida-binding peptides with species-specific properties: novel approach for development of contraceptive vaccines for wildlife. Journal of Biotechnology 162 311-318. (doi:10.1016/j. jbiotec.2012.10.006)

Sanchez-Luengo S, Aumuller G, Albrecht M, Sen PC, Rohm K \& Wilhelm B 2004 Interaction of PDC-109, the major secretory protein from bull seminal vesicles, with bovine sperm membrane $\mathrm{Ca}^{2+}$-ATPase. Journal of Andrology 25 234-244. (doi:10.1002/j.1939-4640.2004.tb02783.x)

Scott TW, Voglmayr JK \& Setchell BP 1967 Lipid composition and metabolism in testicular and ejaculated ram spermatozoa. Biochemical Journal 102 456-461.

Shah GN, Ulmasov B, Waheed A, Becker T, Makani S, Svichar N, Chesler M \& Sly WS 2005 Carbonic anhydrase IV and XIV knockout mice: roles of the respective carbonic anhydrases in buffering the extracellular space in brain. PNAS 102 16771-16776. (doi:10.1073/pnas.0508449102)

Shum WW, Ruan YC, Da Silva N \& Breton S 2011 Establishment of cell-cell cross talk in the epididymis: control of luminal acidification. Journal of Andrology 32 576-586. (doi:10.2164/jandrol.111.012971)

Sleight SB, Miranda PV, Plaskett NW, Maier B, Lysiak J, Scrable H, Herr JC \& Visconti PE 2005 Isolation and proteomic analysis of mouse sperm detergent-resistant membrane fractions: evidence for dissociation of lipid rafts during capacitation. Biology of Reproduction 73 721-729. (doi:10.1095/biolreprod.105.041533)
Smith GD, Wolf DP, Trautman KC, da Cruz e Silva EF, Greengard P \& Vijayaraghavan S 1996 Primate sperm contain protein phosphatase 1, a biochemical mediator of motility. Biology of Reproduction 54 719-727. (doi:10.1095/biolreprod54.3.719)

Stein KK, Go JC, Lane WS, Primakoff P \& Myles DG 2006 Proteomic analysis of sperm regions that mediate sperm-egg interactions. Proteomics 6 3533-3543. (doi:10.1002/pmic.200500845)

Suarez SS, Vincenti L \& Ceglia MW 1987 Hyperactivated motility induced in mouse sperm by calcium ionophore A23187 is reversible. Journal of Experimental Zoology 244 331-336. (doi:10.1002/jez.1402440218)

Sullivan R \& Saez F 2013 Epididymosomes, prostasomes, and liposomes: their roles in mammalian male reproductive physiology. Reproduction 146 R21-R35. (doi:10.1530/REP-13-0058)

Suryawanshi AR, Khan SA, Gajbhiye RK, Gurav MY \& Khole VV 2011 Differential proteomics leads to identification of domain-specific epididymal sperm proteins. Journal of Andrology 32 240-259. (doi:10. 2164/jandrol.110.010967)

Syntin P, Dacheux F, Druart X, Gatti JL, Okamura N \& Dacheux JL 1996 Characterization and identification of proteins secreted in the various regions of the adult boar epididymis. Biology of Reproduction $\mathbf{5 5}$ 956-974. (doi:10.1095/biolreprod55.5.956)

Taylor A, Robson A, Houghton BC, Jepson CA, Ford WC \& Frayne J 2013 Epididymal specific, selenium-independent GPX5 protects cells from oxidative stress-induced lipid peroxidation and DNA mutation. Human Reproduction 28 2332-2342. (doi:10.1093/humrep/det237)

Turner RM 2006 Moving to the beat: a review of mammalian sperm motility regulation. Reproduction, Fertility, and Development 18 25-38. (doi:10. 1071/RD05120)

Turner TT, Plesums JL \& Cabot CL 1979 Luminal fluid proteins of the male rat reproductive tract. Biology of Reproduction 21 883-890. (doi:10.1095/biolreprod21.4.883)

Varano G, Lombardi A, Cantini G, Forti G, Baldi E \& Luconi M 2008 Src activation triggers capacitation and acrosome reaction but not motility in human spermatozoa. Human Reproduction 23 2652-2662. (doi:10. 1093/humrep/den314)

Vijayaraghavan S, Bhattacharyya A \& Hoskins DD 1989 Calcium uptake by bovine epididymal spermatozoa is regulated by the redox state of the mitochondrial pyridine nucleotides. Biology of Reproduction $\mathbf{4 0}$ 744-751. (doi:10.1095/biolreprod40.4.744)

Vijayaraghavan S, Stephens DT, Trautman K, Smith GD, Khatra B, da Cruz eSE \& Greengard P 1996 Sperm motility development in the epididymis is associated with decreased glycogen synthase kinase- 3 and protein phosphatase 1 activity. Biology of Reproduction 54 709-718. (doi:10.1095/biolreprod54.3.709)

Visconti PE, Moore GD, Bailey JL, Leclerc P, Connors SA, Pan D, Olds-Clarke P \& Kopf GS 1995 Capacitation of mouse spermatozoa. II. Protein tyrosine phosphorylation and capacitation are regulated by a cAMP-dependent pathway. Development 121 1139-1150.

Wandernoth PM, Raubuch M, Mannowetz N, Becker HM, Deitmer JW, Sly WS \& Wennemuth G 2010 Role of carbonic anhydrase IV in the bicarbonate-mediated activation of murine and human sperm. PLoS ONE 5 e15061. (doi:10.1371/journal.pone.0015061)

Wang H, Liu J, Cho KH \& Ren D 2009 A novel, single, transmembrane protein CATSPERG is associated with CATSPER1 channel protein. Biology of Reproduction 81 539-544. (doi:10.1095/biolreprod.109. 077107)

Wang L, Yuan Q, Chen S, Cai H, Lu M, Liu Y \& Xu C 2012 Antimicrobial activity and molecular mechanism of the CRES protein. PLOS ONE 7 e48368. (doi:10.1371/journal.pone.0048368)

Wang G, Guo Y, Zhou T, Shi X, Yu J, Yang Y, Wu Y, Wang J, Liu M, Chen X et al. 2013 In-depth proteomic analysis of the human sperm reveals complex protein compositions. Journal of Proteomics 79 114-122. (doi:10.1016/j.jprot.2012.12.008)

Weissgerber P, Kriebs U, Tsvilovskyy V, Olausson J, Kretz O, Stoerger C, Mannebach S, Wissenbach U, Vennekens R, Middendorff R et al. 2012 Excision of Trpv6 gene leads to severe defects in epididymal $\mathrm{Ca}^{2+}$ absorption and male fertility much like single D541A pore mutation. Journal of Biological Chemistry 287 17930-17941. (doi:10.1074/jbc. M111.328286)

Wennemuth G, Babcock DF \& Hille B 2003a Calcium clearance mechanisms of mouse sperm. Journal of General Physiology 122 115-128. (doi:10.1085/jgp.200308839) 
Wennemuth G, Carlson AE, Harper AJ \& Babcock DF 2003 b Bicarbonate actions on flagellar and $\mathrm{Ca}^{2+}$-channel responses: initial events in sperm activation. Development 130 1317-1326. (doi:10.1242/dev.00353)

White DR \& Aitken RJ 1989 Relationship between calcium, cyclic AMP, ATP, and intracellular $\mathrm{pH}$ and the capacity of hamster spermatozoa to express hyperactivated motility. Gamete Research 22 163-177. (doi:10. 1002/mrd.1120220205)

White IG \& VogImayr JK 1986 ATP-induced reactivation of ram testicular, cauda epididymal, and ejaculated spermatozoa extracted with Triton X-100. Biology of Reproduction 34 183-193. (doi:10.1095/biolreprod34.1.183)

Xie F, Garcia MA, Carlson AE, Schuh SM, Babcock DF, Jaiswal BS, Gossen JA, Esposito G, van Duin M \& Conti M 2006 Soluble adenylyl cyclase (sAC) is indispensable for sperm function and fertilization. Developmental Biology 296 353-362. (doi:10.1016/ j.ydbio.2006.05.038)

Yamaguchi Y \& Ouchi Y 2012 Antimicrobial peptide defensin: identification of novel isoforms and the characterization of their physiological roles and their significance in the pathogenesis of diseases. Proceedings of the Japan Academy. Series B, Physical and Biological Sciences 88 152-166. (doi:10.2183/pjab.88.152)

Zhao C, Huo R, Wang FQ, Lin M, Zhou ZM \& Sha JH 2007 Identification of several proteins involved in regulation of sperm motility by proteomic analysis. Fertility and Sterility 87 436-438. (doi:10.1016/j.fertnstert. 2006.06.057)

Zhou CX, Zhang YL, Xiao L, Zheng M, Leung KM, Chan MY, Lo PS, Tsang LL, Wong HY, Ho LS et al. 2004 An epididymis-specific $\beta$-defensin is important for the initiation of sperm maturation. Nature Cell Biology $\mathbf{6}$ 458-464. (doi:10.1038/ncb1127)

Received 3 September 2013

First decision 30 September 2013

Revised manuscript received 14 October 2013

Accepted 5 November 2013 